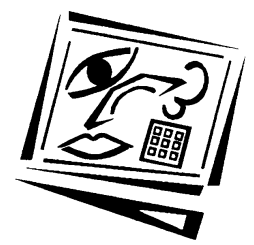

\title{
LiveUSB Mediated Education: A method to facilitate computer supported education
}

\author{
Ramon Garrote \\ University of Borås and Stockholm University \\ Tomas Pettersson \\ University of Borås \\ Michael Christie \\ Stockholm University
}

\begin{abstract}
In this paper the authors analyse the design and implementation of a course about learning management systems (LMS). The course was first given in Cuba and then in Guatemala and Peru, within the project USo+I: Universidad, Sociedad e Innovación, Mejora de la pertinencia de la educación en las ingenierías de Latinoamérica financed by the European Union's ALFA III program. In the course only open educational resources (OER) were used and all course material was stored on USB drives together with the needed software. All programs were executable directly from the memory to meet any problems of limited access to the Internet. Problem based learning was used, with the course divided into two weeks of on campus lectures and workshops followed by distance learning for three months, altogether corresponding to ten weeks of full time studies. The authors propose the term LiveUSB Mediated Education (LUME) for a course package, with course material and software contained on the same USB drive. The participants' opinions about the course and their perceptions about LMS and OER were investigated in order to determine the extent to which the LUME method can facilitate cost-effective computer aided education, especially in developing countries.
\end{abstract}

\section{Background}

The UNESCO Global Education Digest for 2009, which compares educational statistics across the world, indicates that developing countries are coming under pressure to provide quality higher education for increasing numbers of students (UNESCO, 2009). The time series data for 1970-2005 (Table 1, pages 226-245) shows, for example, that Latin America and the Caribbean had an average growth of tertiary education enrolments between 2006 and 2007 of 6.8\%, compared with 0.9\% for North America and Western Europe. Because of severe economic restraints, developing countries have problems meeting this demand while at the same time recognising that higher education is an important ingredient in the securing a better economic future in a more globalised economy. The use of information and communication technology (hereafter ICT) is often seen as a possible panacea for providing more quality higher education at a reduced cost.

The economic usefulness of ICT in higher education has been argued elsewhere (Bates, 2005; Vilaseca \& Castillo, 2008). A lot more research still needs to be done before one can argue conclusively that the pedagogical use of ICT will save universities money while maintaining quality standards. Most research in the area has concentrated on 
pedagogical rather than economic benefits (Lim, 2001; Lim, Khine, Hew, Wong, Divaharan \& Lim, 2003) with the emphasis on compulsory schooling rather than tertiary education.

To facilitate tertiary education by the proper use of ICT is currently a major challenge for higher education institutions in developing countries. The educational benefits of ICT depend both on ease of access and the pedagogical way in which it is applied. In developed countries access to computers and the Internet is taken for granted and computers are used throughout the whole education system. In many cases ICT appears to enhance educational procedures and outcomes, although sometimes the effects are unclear or even detrimental (Lauricella \& Kay, 2010). A viable infrastructure with good access to modern computers and fast Internet connections appear to be necessary conditions for the best use of ICT in education. However, as earlier research in this and other journals indicates, teachers must be prepared (Bain \& McNaught, 2006; Garrote, Pettersson \& Christie, 2007; Garrote \& Pettersson, 2007) if they are to use ICT effectively in order to facilitate quality learning and at the same time save money. A problem facing many developing countries is that for economic and, at times, political reasons, ICT infrastructure and access is limited. However, it appears that access to computers and the Internet will go on increasing in most developing countries (Dutta \& Mia, 2009). In this article we argue that preparing teachers and educational institutions to cope with this phenomenon is of critical importance for education in developing countries (Romiszowski, 2003).

Although economic restraints are clearly a factor in the educational use of ICT in developing countries, this paper makes the case for an innovative and pedagogical use of free educational software and course material that is available on the Internet. Free software and content is known as open educational resources (OER). The term was adopted at a UNESCO meeting in 2002 (D'Antoni, 2008). The OER movement and similar initiatives have generated an impressive amount of free material. Raising the awareness of OER and how it might contribute to the improvement of tertiary education in developing countries has been studied by a number of scholars (Abelson, 2008; D'Antoni, 2009; Dinevski, 2008; Garrote et al., 2010). To utilise the free material, teachers need access to computers and the Internet, basic computer skills and software to handle the material. An increasingly common way of handling this material in developed educational settings is to use what is called a learning management system (hereafter LMS).

LMS are computer programs that integrate functions for teaching, evaluation and the administration of courses. A modern LMS has many features such as shared documents, discussion boards, assessments, a grade book and chat room (Coates, 2005; Sigrén \& Holmqvist, 2005). When a LMS is implemented at an institution and is established as a common tool for the teachers, it becomes easier to utilise OER, adapt courses to blended and distance education, and to use alternatives to conventional classroom teaching (Garrison \& Vaughan, 2008; Khosrowpour, 2002; Lockard \& Pegrum, 2007; Lockwood \& Gooley, 2001). Problem based learning (hereafter PBL) is one example of an alternative type of pedagogy that is well suited to online learning that makes use of LMS.

The issue facing the authors of this paper was how to make use of LMS in developing countries where economic feasibility is an important issue. Commercial learning management systems such as Blackboard are very costly to implement and maintain. Not enough research has been done in the area but it would be interesting to know the 
cost benefits of using LMS in western universities over the last decade. A disadvantage is that universities start paying for LMS immediately, but the effective use of it by teachers and students takes time. Western universities have had the will and the money to invest in this development. Universities in developing countries are less privileged which helps explain the difficulty in bridging the digital divide between rich and poor countries. Fortunately there are several LMS available as free open source software, with similar features to those in the commercial products (Grob, Bensberg \& Dewanto, 2004; Sife, Lwoga \& Sanga, 2007; Cavus, Uzunboylu \& Ibrahim, 2008).

\section{Adaptation of engineering education to the use of Net independent software}

In the year 2010 the University of Borås (Borås, Sweden) was asked to give Latin American engineering educators a course about LMS within the project USo+i: Universidad, Sociedad e Innovación. Mejora de la pertinencia de la educación en las ingenierías de Latinoamérica (University and Society: Improving the relevance of the engineering education in Latin America) financed by the European Union, within the ALFA III program. The first author of this paper designed the course Adaptation of engineering education to the use of net independent software that was then registered as a 15 ECTScredits (European Credit Transfer and Accumulation System) course at the School of Engineering, University of Borås.

The main objective of the course was to give the participating lecturers the necessary skills to handle a LMS. It was important to inspire them to act as pioneers in their workplaces and prepare them to give courses about the handling of a LMS as well as support other teachers who wished to try using the software (Birch \& Burnett, 2009; Uys, 2010). Since one important aspect of a LMS is the convenience with which OER can be incorporated into the system, it was desirable to draw the participants' attention to the availability of free resources that can be found on the Internet. The problem we mentioned in the introduction remained however. In the countries where we were to hold the course there was limited access to both computers and the Internet. To solve the problem, both in terms of the course and for the participants' future practice, we needed to create a pedagogical sound ICT method that would work without Internet connection and on any available computer.

These considerations led to the decision to use OER and copy all course material and software on a 4 GB USB drive (or USB flash drive, or "memory stick", or "traveling disk", etc) for each participant. As the LMS for the course, Moodle (moodle.org, 2010) was selected. The intention was to find a suitable LMS for this and future courses, and also provide a free alternative to the commercial products.

On the USB drive the programs Moodle, Sumatra PDF, VLC media player, LyX, HotPotatoes 6, AbiWord, MoWeS II and OpenOffice.org Portable were stored together with more than 50 Spanish-language videos with practical guides about how to use Moodle, downloaded from YouTube. Since all computers that would be used during the course had some version of Windows installed only applications that worked with Windows were selected and no operating system was supplied.

Pedagogically, the course was formed around the main assignment for each participant. The students' task was to select a course from their practice and adapt the existing course material to the LMS, possibly add some new material and prepare for the appropriate use of tools such as discussion boards, grade book, etc, when teaching 
the course in the future. Our philosophical approach was constructivist and made use of the theory that learners build their own knowledge from information, previous experience, interactions with others and analytical, critical reflection (Forman et al., 1996; Harel et al., 1991; Kafai \& Resnick, 1996; Kukla, 2000). That pedagogical method we used can be best described as problem based learning (PBL). We used a teacher directed form of PBL where the learning outcomes are to be achieved by students working on problems that are presented at the beginning of the course. The participants can find and use any information they need to solve the problems.

Although we anticipated that this approach might be unusual for our Latin American students we wanted the students to develop their skills in handling information, and to take more responsibility for their learning process. The emphasis on self acquired skills was important because our students were expected to, in their turn, motivate other teachers to be self activating in the use of ICT in their courses. The literature provides convincing evidence that PBL develops problem solving and information handling skills that better equip learners to deal with real life situations than memorised knowledge from textbooks. (Barrows \& Tamblyn, 1980; Björck, 2004; Boud \& Feletti, 1991).

The course was given for the first time by the first author of this paper in Cuba in March 2010. The participants were lecturers at the Instituto Superior Politécnico José Antonio Echeverría ISPJAE, Facultad de Ingeniería Eléctrica, Havana, Cuba. The course was given in two parts. For the first part the participants were gathered on campus for a two week period with the lecturer. The second part consisted of work on the given assignments over the following three months. During that period the first author of this paper was available for advice, mainly by email, but also by regular or Internet telephone.

In total this course corresponded to ten weeks of full time study or 15 ECTS points. To pass the course, the participants had to participate actively during the first part, present their initial work in a seminar at the end of the first two week period, and submit a final report to the lecturer. The final report had to document how they adapted a course of their choice to the use of a LMS, their perceptions about the use of a LMS, and their assessment of the other participants' solutions.

The second time the course was given was in May 2010. This time the participants were teachers from Centro Universitario de Occidente - Universidad de San Carlos, CUNOC-USAC. Quetzaltenango, Guatemala. The same format was repeated with an on campus and distance learning component. The course was given a third time at Universidad Ricardo Palma (URP) in Santiago de Surco, Peru, again with the same teaching and learning conditions and the same number of course credits.

When the course in Cuba concluded, 13 out of 15 participants had passed. In Cuba the university strongly supported the course and the participants were highly motivated; two participants were unable to complete the course because they took up new work positions.

In Guatemala 14 out of 21 participants passed the course. In Guatemala the institutional support was not as strong as in Cuba and it was more of a personal choice to complete the course. The course has since been given to lecturers at Universidad de San Carlos de Guatemala, Guatemala City, with the same course material and one of 
the original participants as lecturer. The first author of this paper acted as advisor and examiner since the course was registered at the University of Borås.

The result in Peru appears slightly disappointing; six participants out of eleven have completed the course to date. However, the result is not bad, given the circumstances. Most lecturers in Peru have a very heavy workload, because they work at more than one place, a common practice in Peru (Vandergaag, Stelcner \& Vijverberg, 1989). For that reason it was hard to gather the group during the first two weeks on campus and most of the participants were unable to spend as much time on the course as intended. In view of these problems two participants have been given additional time to complete their assignments.

\section{LiveUSB mediated education: LUME}

The idea to store and distribute complete course materials that can run on any computer is not new. Before the advent of reasonably priced USB drives with sufficient capacity, removable hard drives were used by teachers to achieve some of the aims we describe in this article (Hailey \& Hailey, 2002). In spring 2009 Thomas Edison State College in the United States began to offer courses packaged on USB drives under the name 'flash track courses' (Mearian, 2009). What we believe is innovative in our approach is the extent to which we use the USB and the purpose for which we use it. Our intention is to use ICT in a pedagogically sound way in order to bridge the digital divide that exists in the tertiary education systems of rich and poor countries.

We have coined the term LiveUSB mediated education or LUME to describe the way in which we have packaged all course material and the software needed to use it on a portable memory device. The term LiveUSB commonly refers to USB drives containing an operating system that operates independently of the operating system that is installed on the computer. However, since we refer to a complete course package, we feel that the term LUME is convenient even if no operating system is included (or if it is attached in some other way, such as on a CD). The point is that the course material and the portable software required to access it are stored and distributed as a package (Garrote \& Pettersson, 2011).

\section{The purpose of this study}

The purpose of this study is to investigate the attitudes of third world engineering educators towards the LUME method and the use of OER in order to determine if the LUME method can contribute to making computer aided education more accessible worldwide.

\section{Scope and limitations}

The course was given, and the survey was carried out, on three occasions, in Cuba, Guatemala and Peru. A limitation of the study is the size of the sample. The Cuban course contained 15 students, the Guatemalan course 21 and the Peruvian course 11 students. The courses were given in engineering departments at each university and although the numbers are small we would argue that the participants' opinions were most likely representative for engineering university lecturers in their country. A much larger survey would have to be conducted to confirm this claim. 


\section{Method}

The participants in the course met on campus for the first two weeks of the course. At the start the participants' prior experience of working with a LMS was investigated, and at the end of the two weeks, questionnaires and group discussions were used to get their opinions about the use of LMS and OER. The questionnaires with opinions about the course were filled in anonymously.

\section{Results and observations}

\section{The teacher's observations}

At the start of the course most of the participants were a little confused with the PBL method and the design of the course. The idea of relying on free material from the Internet (in particular videos) for instruction in a course at university level was new to them, but within a few days the work was running smoothly with an apparent high level of cooperation and creativity.

The most important difference between the Cuban group and the others was the lack of computers and the extremely limited Internet access in Cuba. That is a problem for both lecturers and students, but the situation is expected to improve (Hoffmann, 2004).

\section{Participants' prior experience}

To assess participants' previous experience with learning management system tools, a questionnaire was given before the course commenced (Table 1).

Table 1: Experience of learning management system (LMS)

\begin{tabular}{|l|l|c|c|}
\hline \multicolumn{1}{|c|}{ I have used } & \multicolumn{1}{c|}{ Country } & Yes & No \\
\hline \multirow{4}{*}{ A. Uploading and sharing material } & Cuba $(\mathrm{n}=15)$ & 3 & 12 \\
\cline { 2 - 4 } & Guatemala $(\mathrm{n}=21)$ & 10 & 11 \\
\cline { 2 - 4 } & Peru $(\mathrm{n}=11)$ & 10 & 1 \\
\hline \multirow{3}{*}{ B. Forums and chats } & Cuba & 3 & 12 \\
\cline { 2 - 4 } & Guatemala & 6 & 15 \\
\cline { 2 - 4 } & Peru & 1 & 10 \\
\hline \multirow{2}{*}{ C. Quizzes and surveys } & Cuba & 1 & 14 \\
\cline { 2 - 4 } & Guatemala & 5 & 16 \\
\cline { 2 - 4 } & Peru & 1 & 10 \\
\hline \multirow{2}{*}{ D. Gathering and reviewing assignments } & Cuba & 0 & 15 \\
\cline { 2 - 4 } & Guatemala & 5 & 16 \\
\cline { 2 - 4 } & Peru & 0 & 11 \\
\hline \multirow{2}{*}{ E. Recording grades } & Cuba & 2 & 15 \\
\cline { 2 - 4 } & Guatemala & 0 & 11 \\
\cline { 2 - 4 } & Peru & & \\
\hline
\end{tabular}

As can be seen in Table 1 a number of the Guatemalan and Peruvian participants had some experience of the tools in a LMS. The result was discussed in the groups and it turned out that their experience was very limited. In the Peruvian group 10 out of 11 participants had used the LMS Moodle to distribute documents, but very little of the other tools, so it did not motivate any changes in the course structure. 


\section{Internet access}

To see whether respondents considered their students' access to computers and the Internet to be a problem, the statement 'Many of my students lack access to computers and / or Internet' was assessed on a five point scale (Table 2).

Table 2: Responses to the statement about Internet access

1 = I fully agree, 2 = I agree, $3=$ Neutral, $4=$ I disagree, $5=$ I strongly disagree

\begin{tabular}{|c|l|l|c|c|c|c|c|}
\hline No. & \multicolumn{1}{|c|}{ Statement } & \multicolumn{1}{|c|}{ Country } & 1 & 2 & 3 & 4 & 5 \\
\hline 1 & $\begin{array}{l}\text { Many of my students lack access } \\
\text { to computers and / or Internet. }\end{array}$ & Cuba $(\mathrm{n}=15)$ & 7 & 4 & 1 & 2 & 1 \\
\cline { 3 - 8 } & Guatemala $(\mathrm{n}=21)$ & 2 & 6 & 1 & 12 & \\
\cline { 3 - 8 } & Peru $(\mathrm{n}=11)$ & & & 5 & 4 & 2 \\
\hline
\end{tabular}

From observations and discussions it was obvious that in Guatemala and Peru it is possible to get Internet access but the cost means that it is not as common a facility as it is in developed countries. All the Guatemalan and Peruvian participants had laptop computers but could only connect to the Internet from stationary computers at the university. For many students the cost of Internet access and computers is still a problem. In Cuba, even university lecturers have to share computers, and they have very limited access to Internet. Very few of their students have any access to computers and the Internet. The responses to statement number one should be interpreted with regard to the respondents' situation; the respondents are likely to compare their students' situation with their own. In the group discussions it was made clear that few students in Cuba have access to computers.

\section{Participants' assessments of the course}

As a part of the course evaluation procedure and to provide input for the further development of the course, all participants filled out an anonymous questionnaire with ten statements and three open ended questions at the end of the second week. Table 2 shows the responses to six of these statements.

Table 3: Anonymous responses to statements in the students' assessment questionnaire 1 = I fully agree, $2=$ I agree, $3=$ Neutral, $4=$ I disagree, $5=$ I strongly disagree

\begin{tabular}{|c|c|c|c|c|c|c|c|}
\hline No. & Statement & Country & 1 & 2 & 3 & 4 & 5 \\
\hline \multirow{3}{*}{2} & \multirow{3}{*}{$\begin{array}{l}\text { I understand the common } \\
\text { features of a LMS }\end{array}$} & Cuba $(n=15)$ & 14 & 1 & & & \\
\hline & & Guatemala $(n=21)$ & 11 & 7 & & & \\
\hline & & Peru $(\mathrm{n}=11)$ & 11 & & & & \\
\hline \multirow[t]{3}{*}{3} & \multirow{3}{*}{$\begin{array}{l}\text { I feel prepared to use a LMS } \\
\text { in my work }\end{array}$} & Cuba & 8 & 7 & & & \\
\hline & & Guatemala & 7 & 10 & 2 & 2 & \\
\hline & & Peru & 8 & 3 & & & \\
\hline \multirow[t]{3}{*}{4} & \multirow{3}{*}{$\begin{array}{l}\text { The course fulfilled my } \\
\text { expectations }\end{array}$} & Cuba & 15 & & & & \\
\hline & & Guatemala & 12 & 9 & & & \\
\hline & & Peru & 11 & & & & \\
\hline \multirow[t]{3}{*}{5} & \multirow{3}{*}{$\begin{array}{l}\text { Videos and other materials } \\
\text { were well suited to the course } \\
\text { objectives }\end{array}$} & Cuba & 15 & & & & \\
\hline & & Guatemala & 16 & 4 & 1 & & \\
\hline & & Peru & 11 & & & & \\
\hline \multirow[t]{3}{*}{6} & \multirow{3}{*}{$\begin{array}{l}\text { There was a high level of } \\
\text { cooperation and interaction } \\
\text { amongst the participants }\end{array}$} & Cuba & 14 & 1 & & & \\
\hline & & Guatemala & 6 & 14 & 1 & & \\
\hline & & Peru & 9 & 2 & & & \\
\hline \multirow[t]{3}{*}{7} & \multirow{3}{*}{$\begin{array}{l}\text { The course objectives agree } \\
\text { with the material covered in } \\
\text { class }\end{array}$} & Cuba & 15 & & & & \\
\hline & & Guatemala & 16 & 5 & & & \\
\hline & & Peru & 11 & & & & \\
\hline
\end{tabular}


Both groups gave the course a high rate of approval; it seems that the group on Cuba was the most enthusiastic and this was confirmed by the first author's observations during the course. Since the questionnaire was filled out when the course was only two weeks under way, the responses to statement number three are understandably reluctant. The responses to statement number five show a high appreciation of videos as a major source of information, which is particularly interesting because at the beginning of the course many participants were rather sceptical about the use of media files instead of a conventional textbook.

\section{Participants attitudes about OER}

The participants assessed the statements 8 and 9 on the same five point scale as above in order to show their opinions about OER (Table 4).

Table 4: Responses to statements about OER

1 = I fully agree, 2 = I agree, 3 = Neutral, 4 = I disagree, 5 = I strongly disagree

\begin{tabular}{|c|c|c|c|c|c|c|c|}
\hline No. & Statement & Country & 1 & 2 & 3 & 4 & 5 \\
\hline \multirow[t]{3}{*}{8} & \multirow{3}{*}{$\begin{array}{l}\text { I believe the use of the free course material on } \\
\text { the Internet (freeware) offers great opportunities } \\
\text { for increasing the quality of higher education. }\end{array}$} & Cuba $(n=15)$ & 12 & 3 & & & \\
\hline & & Guatemala $(\mathrm{n}=21)$ & 14 & 6 & 1 & & \\
\hline & & Peru $(\mathrm{n}=11)$ & 10 & & 1 & & \\
\hline \multirow[t]{3}{*}{9} & \multirow{3}{*}{$\begin{array}{l}\text { I am willing to make a lot of my course material } \\
\text { available as freeware on the Internet. }\end{array}$} & Cuba & 13 & 2 & & & \\
\hline & & Guatemala & 11 & 9 & 1 & & \\
\hline & & Peru & 10 & 1 & & & \\
\hline
\end{tabular}

In Table 4 the responses demonstrate a very positive attitude towards OER and the discussions in the groups confirmed that the participants were impressed by the abundance of available material on the Internet. The group in Guatemala was slightly more reluctant, but still had a positive attitude about OER. A bigger difference can be seen in the responses to statement 9, where the Guatemalan group shows a slight reluctance to share course material.

\section{Participants attitudes about LMS}

To investigate the participants' perceptions about LMS a similar set of statements was used (see Table 5).

Table 5: Responses to statements about LMS

1 = I fully agree, 2 = I agree, 3 = Neutral, 4 = I disagree, 5 = I strongly disagree

\begin{tabular}{|l|l|l|c|c|c|c|c|}
\hline No. & \multicolumn{1}{|c|}{ Statement } & \multicolumn{1}{|c|}{ Country } & 1 & 2 & 3 & 4 & 5 \\
\hline 10 & $\begin{array}{l}\text { A LMS can facilitate the work of the lecturers to } \\
\text { a large extent. }\end{array}$ & Cuba $(\mathrm{n}=15)$ & 12 & 3 & & & \\
\hline & & Guatemala $(\mathrm{n}=21)$ & 10 & 11 & & & \\
\hline & & Peru $(\mathrm{n}=11)$ & 8 & 3 & & & \\
\hline 11 & $\begin{array}{l}\text { A LMS can increase the performance of the } \\
\text { students at my institution. }\end{array}$ & Cuba & 9 & 6 & & & \\
\hline & Guatemala & 16 & 5 & & & \\
\hline & Peru & 9 & 2 & & & \\
\hline
\end{tabular}

The responses in Table 5 show that all three groups believe that a LMS can be a very useful tool in their work. The participants in Guatemala are a little more reluctant in their responses, but in the discussions there was no apparent difference between the groups concerning statement 10. Students in Guatemala and Peru usually have access to computers and the Internet, and the Guatemalan and Peruvian participants in this course were very interested in the possibility of using features like discussion boards 
to enhance the students' activities. The Cuban lecturers have very limited access to the Internet and while that situation may improve within a couple of years there is still some doubt that enough students will have sufficient access to computers and Internet to make it feasible to use the LMS tools.

To investigate how the participants perceived the method of executing programs directly from a USB drive, two additional statements were assessed by the groups in Guatemala and Peru (Table 6).

Table 6: Responses to statements about the use of USB memories 1 = I fully agree, 2 = I agree, 3 = Neutral, $4=$ I disagree, $5=$ I strongly disagree

\begin{tabular}{|c|l|l|c|c|c|c|c|}
\hline No. & \multicolumn{1}{|c|}{ Statement } & \multicolumn{1}{|c|}{ Country } & 1 & 2 & 3 & 4 & 5 \\
\hline 12 & $\begin{array}{l}\text { The ability to run programs from a USB drive } \\
\text { significantly improved the learning experience. }\end{array}$ & $\begin{array}{l}\text { Guatemala } \\
(\mathrm{n}=21)\end{array}$ & 17 & 4 & & & \\
\cline { 3 - 7 } & & Peru (n=11) & 9 & 2 & & & \\
\hline 13 & $\begin{array}{l}\text { The use of a USB drive to emulate the resources } \\
\text { of the Internet makes it much more feasible to } \\
\text { use open educational resources (OER). }\end{array}$ & Guatemala & 14 & 7 & & & Peru \\
\hline
\end{tabular}

With the LMS executed from the USB drive it was possible to try out the program with full access, that is, as an 'administrator' not just as a 'user'. The responses to statement number 12 strongly support the assumption that it is highly desirable to be able to try out a program freely, without restrictions and concerns about security and access levels.

It is a little surprising to see the strong support for statement 13. In Cuba it is necessary to use some kind of memory device to use videos and the necessity to take turns on different computers would have made it highly inconvenient to work without USB drives.

For the Guatemalan and Peruvian groups it was more a matter of convenience and flexibility. In both Guatemala and Peru, Internet access is generally good enough to access a lot of OER online, for example media files.

The participants in Guatemala had laptop computers, without Internet connection, during the course. As mentioned above, in order to access the Internet at work they had to use stationary computers at the university, but many had an Internet connection at home. In Peru the course was given in a classroom equipped with computers with Internet connections. Internet transmission was slow and there were a lot of restrictions to accessing Internet pages. For example, YouTube was not available.

\section{Summation}

All participants were positive about the pedagogical and methodological aproach used in the course. They agreed that a LMS can be very useful in their future practice and that the use of OER can be highly beneficial to the educational process. The participants' high appreciation of the course together with their positive attitudes about OER and the use of LMS strongly indicates that they are well prepared to increase the use of ICT in their work. They appear to be ready to use OER in the same way as they used them in this course, with a USB drive and a LMS to organise the material. The positive assessments for the course were probably due to the close connection between design and content. The course immediately demonstrated how to 
utilise OER in a way that enabled lecturers themselves to begin integrating the method into their own teaching practice. The method of running the LMS from a USB drive was highly appreciated.

\section{Discussion}

We assert that our LUME approach can save developing countries considerable amounts of money by introducing and educating university lecturers in the pedagogical use of LMS in on campus, blended and distance learning. The fact that teachers can use freeware almost exclusively saves money while at the same time the appropriate use of ICT will help developing universities deal with increasing numbers of students. In some senses these universities have an opportunity to leap frog some of the costly investments that universities in developed countries have made over the last decade. The comparative cost and capacity of a USB drive today compared with a few years back is a good example. Developing countries can also learn from some of the mistakes made in the poor implementation of online learning (Christie \& Garrote, 2007).

To utilise OER is an economically feasible way for educational institutions in developing countries to meet the challenge of integrating ICT into tertiary teaching and learning. But, the transition from a teacher-to-student, textbook based pedagogy, to the creation of a progressive and flexible learning environment can only be successful if it is supported by the educators. Changing educational practice must start with staff development. Teachers need the skills to handle ICT and the pedagogical and methodological challenges that employing it in course work demands. It is important that development courses in this area not only build the teacher's technical skills but also introduce them to creative ways of getting the most out of the technology from a teaching and learning perspective (Zhou \& Xu, 2007).

To make computer-assisted education more generally available to people in developing countries, we strongly advocate the use of OER. There is a lot of material available, but it is not easy to utilise OER in developing countries where most people do not have a computer of their own and Internet connections are relatively expensive. It is to be expected that access to computers and the Internet will increase even in the poorest countries in the next few years. The LUME method that we advocate provides educational materials free (most OER) or at affordable prices and can be used anywhere, at any time and on any computer. In a place like Cuba where there is a well developed national intranet such an initiative is both cost effective and educationally sound.

In Open educational resources: The way forward (D'Antoni, 2008) the future development of OER is discussed. Awareness raising, building and supporting communities, capacity development, sustainability and quality assurance are pointed out as the five most important issues in the future. A combination of the LUME method and OER can have a beneficial impact on all five points. The first two issues are obviously addressed since the method gives many educators in developing countries, with limited Internet access, a tool to utilise OER in their practice and to cooperate in the planning of courses that utilise OER. Capacity development will also be enhanced by the LUME method. Probably not the production of new OER material, but the use, the re-use and the re-mixing of OER to form and implement courses is facilitated by LUME. 
Sustainability and quality assurance are closely connected. With so much material freely available on the Internet, the selection of educational material is crucial for the quality of OER-based courses. With LUME, teachers or educational institutions can pick and choose from the free material on the Internet, organise the material, possibly add some of their own and then distribute it as a complete package. In such a situation, the course package will be the creation of the teacher or institution and as such should provide some guarantees concerning the quality of the course.

The course Adaptation of engineering education to the use of Net independent software is an example of how that procedure can work. Once the course is put together and given for the first time the participants may use the material to give the course to others. The course package has thus been re-used in both Cuba and Guatemala.

OER together with the LUME method is a feasible solution to providing training to large numbers of university teachers in developing countries. The advent of cheap USB drives with large memory capacity means that materials for lifelong learning, distance learning, self study as well as on campus and blended learning can be distributed at low cost and utilised without regard to the availability or cost of Internet connections.

Flexibility is a strong argument for LUME even if access to the Internet and personal computers is good, but it is in developing countries, where relatively few people have computers and connection to the Internet is both patchy and expensive, that the method can make the most difference. In such a context, it is obviously of paramount importance to make use of OER. Freeware opens up opportunities for both teachers and students in countries where many people are otherwise excluded from education. There may be different reasons why OER is still not an everyday tool in developing countries, but the teachers' low awareness about OER probably plays a significant role in this.

\section{Conclusions and recommendations}

The possibility of utilising OER on a wide scale in order to improve the quality of tertiary education and make it more accessible to a growing number of students in developing countries is a strong argument in favor of ICT in education. For teachers in developing countries the LUME method offers a complete tool for getting the most out of OER, notwithstanding Internet connections being scarce or expensive. OER can be adapted for courses and then copied on to USB drives. During courses the students can work off line on any available computer and they have to connect to the Internet to upload material only if the course is electronically mediated. The authors urge educational institutions, particularly in developing countries, to promote the use of OER and recommend the LUME method as a highly convenient tool to both educate the teachers and help them use OER in their own courses.

\section{Acknowledgments}

This work has been produced with financial assistance from the European Community; contract DCI-ALA/19.09.01/08/ 19189/160-922/ALFA III-9. The contents are the sole responsibility of the authors and in no way to be regarded as reflecting the official views of the European Union.

The authors thank Rector PhD Lena Nordholm and the University of Borås for encouragement and main funding of our work. 


\section{References}

Abelson, H. (2008). The creation of open courseware at MIT. Journal of Science Education and Technology, 17(2), 164-174. http:/ / dx.doi.org/10.1007/s10956-007-9060-8

Bain, J. D. \& McNaught, C. (2006). How academics use technology in teaching and learning: Understanding the relationship between beliefs and practice. Journal of Computer Assisted Learning, 22(2), 99-113. http:/ / dx.doi.org/10.1111/j.1365-2729.2006.00163.x

Barrows, H. S. \& Tamblyn, R. M. (1980). Problem-based learning: An approach to medical education. New York: Springer.

Bates, T. (2005). Technology, e-learning and distance education (2nd ed.). London; New York: Routledge.

Birch, D. \& Burnett, B. (2009). Bringing academics on board: Encouraging institution-wide diffusion of e-learning environments. Australasian Journal of Educational Technology, 25(1), 117134. http:/ / www.ascilite.org.au/ajet/ajet25/birch.pdf

Björck, U. (2004). Distributed problem-based learning: Studies of a pedagogical model in practice. Göteborg: Acta Universitatis Gothoburgensis. http: / / www.dissertations.se/dissertation/8279b3a793/

Boud, D. \& Feletti, G. (1991). The challenge of problem based learning. London: Kogan Page.

Cavus, N., Uzunboylu, H. \& Ibrahim, D. (2008). Student opinion towards using an open source learning management system together with a collaborative tool. Cypriot Journal of Educational Sciences, 3(2), 120-129. http: / / www.world-educationcenter.org/index.php/cjes/article/view/34/30

Christie, M. \& Garrote, R. (2007). UkeU and Sweden's Net University: A comparative study. Paper presented at the International Conference on Engineering and Education Research (iCEER 2007). Melbourne, 2-7 December.

Coates, H., James, R. \& Baldwin, G. (2005). A critical examination of the effects of learning management systems on university teaching and learning. Tertiary Education and Management, 11(1), 19-36. http: / / dx.doi.org/10.1007/ s11233-004-3567-9

D'Antoni, S. (2008). Open educational resources: The way forward - Deliberations of an international community of interest. Paris: UNESCO Institute for Educational Planning (IIEP). [not available 20 Jul 2011] http:/ / oerwiki.iiep.unesco.org/index.php/OER:_the_Way_Forward

D'Antoni, S. (2009). Open educational resources: Reviewing initiatives and issues. Open Learning, 24(1), 3-10. http: / / dx.doi.org/10.1080/02680510802625443

Dinevski, D. (2008). Open educational resources and lifelong learning. In ITI 2008: 30th International Conference on Information Technology Interfaces, 117-122. http: / / dx.doi.org/10.1109/ITI.2008.4588393

Dutta, S., \& Mia, I. (2009). The global information technology report 2008-2009. Geneva: World Economic Forum. [verified 20 Jul 2011; 2.2 MB] http:/ / ifap.ru/library/book420.pdf

Forman, E. A., Minick, N. \& Stone, C. A. (1996). Contexts for learning: Sociocultural dynamics in children's development. New York: Oxford University Press.

Garrison, D. R. \& Vaughan, N. D. (2008). Blended learning in higher education. San Francisco, CA: Wiley. 
Garrote, R. \& Pettersson, T. (2007). Lecturers' attitudes about the use of learning management systems in engineering education: A Swedish case study. Australasian Journal of Educational Technology, 23(3), 327-349. http:/ / www.ascilite.org.au/ajet/ ajet23/garrote.html

Garrote, R. \& Pettersson, T. (2011). LiveUSB mediated education (LUME). International Journal of Education and Development using ICT, 7(1). http: / / ijedict.dec.uwi.edu / include / getdoc.php?id=4473\&article=1209\&mode=pdf

Garrote, R., Pettersson, T. \& Christie, M. F. (2007). Lärares attityder till användningen av lärplattformar i högre utbildning. Göteborg: Chalmers IT University of Göteborg. http: / / bada.hb.se/ bitstream/2320/2138/1/Garrote_mfl_Larares_attityder_till.pdf

Garrote, R., Pettersson, T., Seoane Martínez, F., Sigrén, P. \& Christie, M. (2010). Training teachers in e-learning without Internet access. EDULEARN10 (pp. 6336-6341), Barcelona, Spain. http: / / www.redusoi.org/docs/publicaciones/Edulearn2010_RAG.pdf

Grob, H. L., Bensberg, F. \& Dewanto, B. L. (2004). Developing, deploying, using and evaluating an open source learning management system. Journal of Computing and Information Technology, 12(2), 127-134.

http: / / hrcak.srce.hr/cit_ojs/index.php/CIT / article/viewFile/1537 / 1241

Hailey, D. E. \& Hailey, C. E. (2002). Overview of a distributed-hard-drive-based educational plan. 2002 ASEE Gulf-Southwest Annual Conference, The University of Louisiana at Lafayette, American Society for Engineering Education. [not available 20 Jul 2011] http: / / www.aseegsw.org/Proceedings/IIA2.pdf

Harel, I. \& Papert, S. (1991). Constructionism: Research reports and essays, 1985-1990. Norwood, NJ: Ablex.

Hoffmann, B. (2004). The politics of the Internet in third world development: Challenges in contrasting regimes with case studies of Costa Rica and Cuba. New York: Routledge.

Kafai, Y. B. \& Resnick, M. (1996). Constructionism in practice: Designing, thinking and learning in a digital world. Mahwah, NJ: Lawrence Erlbaum Associates.

Khosrowpour, M. (2002). Web-based instructional learning. Hershey, PA: IRM Press.

Kukla, A. (2000). Social constructivism and the philosophy of science. New York: Routledge.

Lauricella, S. \& Kay, R. (2010). Assessing laptop use in higher education classrooms: The laptop effectiveness scale (LES). Australasian Journal of Educational Technology, 26(2), 151-163. http: / / www.ascilite.org.au/ajet/ajet26/lauricella.html

Lim, C. P. (2001). Object of the activity systems as a major barrier to the creative use of ICT in schools. Australian Journal of Educational Technology, 17(3), 295-312. http: / / www.ascilite.org.au/ajet/ajet17/lim.html

Lim, C. P., Khine, M. S., Hew, T., Wong, P., Divaharan, S. \& Lim, B.(2003). Exploring critical aspects of information technologies integration in Singapore schools. Australian Journal of Educational Technology, 19(1), 1-24. http:/ / www.ascilite.org.au/ajet/ajet19/lim.html

Lockard, J. \& Pegrum, M. (2007). Brave new classrooms. New York: Peter Lang.

Lockwood, F. \& Gooley, A. (2001). Innovation in open and distance learning. London: Kogan Page. 
Mearian, L. (2009). College puts entire courses on USB drives. Computerworld, 16 November. [viewed 10 Jul 2008; verified 19 Jul 2010] http: / / www.computerworld.com/s / article/ 9140951/College_puts_entire_courses_on_USB_drives

Moodle (2010). Open-source community-based tools for learning. [viewed 10 Apr 2008] http:/ / moodle.org/

Romiszowski, A. (2003). The future of e-learning as an educational innovation: Factors influencing project success and failure. Associação Brasileira de Educação a Distância. http: / / www.abed.org.br/revistacientifica/Revista_PDF_Doc/2003_Future_E_Learning_Ed ucational_Innovation_Alexander_Romiszowski.pdf

Sife, A. S., Lwoga, E. T. \& Sanga, C. (2007). New technologies for teaching and learning: Challenges for higher learning institutions in developing countries. International Journal of Education and Development using ICT, 3(2). http: / /ijedict.dec.uwi.edu/viewarticle.php?id=246

Sigrén, P. \& Holmqvist, H. (2005). Syntes och analys av tidigare kravspecifikationer för upphandling av lms inom den svenska högskolan 2000 - 2004 Härnösand: Myndigheten för Sveriges nätuniversitet. http:/ / bada.hb.se/ bitstream/2320/2076/1/LMS_Rapport.pdf

Stewart, B., Briton, D., Gismondi, M., Heller, B., Kennepohl, D., McGreal, R. \& Nelson, C. (2007). Choosing MOODLE: An evaluation of learning management systems at Athabasca University. International Journal of Distance Education Technologies, 5(3). http: / / dx.doi.org/10.4018/jdet.2007070101

UNESCO (2009). Global Education Digest 2009: Comparing Education Statistics Across the World. UNESCO Institute of Statistics, Montreal. [verified 20 Jul 2010; 7102 kB] http: / / www.uis.unesco.org/Library / Documents/ged09-en.pdf

Uys, P. M. (2010). Implementing an open source learning management system: A critical analysis of change strategies. Australasian Journal of Educational Technology, 26(7), 980-995. http: / / www.ascilite.org.au/ajet/ajet26/uys.html

Vandergaag, J., Stelcner, M. \& Vijverberg, W. (1989). Wage differentials and moonlighting by civil-servants - evidence from Ivory Coast and Peru. World Bank Economic Review, 3(1), 67-95.

Vilaseca, J. \& Castillo, D. (2008). Economic efficiency of e-learning in higher education: An industrial approach. Intangible Capital, 4(3), 191-211.

http: / / www.intangiblecapital.org/index.php/ic/article/view/88/84

Zhou, G. \& Xu, J. (2007). Adoption of educational technology ten years after setting strategic goals: A Canadian university case. Australasian Journal of Educational Technology, 23(4), 508528. http:/ / www.ascilite.org.au/ajet/ajet23/ zhou.html

Authors: Ramon Garrote Jurado, Center for Learning and Teaching, University of Borås, Sweden. Email: ramon.garrote@hb.se

Tomas Pettersson, Center for Learning and Teaching, University of Borås, Sweden. Email: tomas.pettersson@hb.se

Michael Christie, Department of Applied Information Technology, University of Gothenburg, Sweden. Email: michael.christie@ituniv.se

Please cite as: Garrote, R., Pettersson, T. \& Christie, M. (2011). LiveUSB Mediated Education: A method to facilitate computer supported education. Australasian Journal of Educational Technology, 27(4), 619-632.

http: / / www.ascilite.org.au/ajet/ajet27/garrote.html 